\title{
PROPERTY STATUS OF ROYALTIES IN CANADIAN OIL AND GAS LAW

\author{
w. H. ELLIS*
}

\begin{abstract}
This paper considers she narure of rke interest created by a rosalty under Concdian and American izl in particular. this poper consuders whether o gross overnding rovalty can be creaced as an inierest in ini under Cancdian low.
\end{abstract}

\section{INTRODUCTION}

This paper inquires into the question of whether it is possible in Canada to create royalties - especially overriding royalties - that are interests in property. Writing in 1966 about a Jasper seminar he had just attended. Professor Andy Thompson said:'

\begin{abstract}
I ventured the opiaion that a profit \& prendre may be suikable for the eategocization of the :Ights conferred by the oil and pas lease because in Endisth and Caudian common law the propin a prendre is a retativety empry veated. There is so little law about the subject that it can all be summed up in two payss of Halsoury's Laws of Endaod. .. An empty veasel is surety an invitation to fill it with a contens which will be appropriate, and therefore Canedian cours have the opportunity to develop the nature of the property interes conferred by the oil and gas lease in sensible response to the exigencies and requirements of a thrivins petroteun industry adequately responsive to the public interest.
\end{abstract}

After almost two decades, the vessel has filled a little, and there is a serious question whether "the exigeacies and requirements of a thriving petroleum industry" have been served in the filling. More specifically, has the decision. to which Professor Thompson alludes, that an oil and gas lease convevs a profit $a$ prendre in Canada, ${ }^{2}$ unwittingly foreclosed the practical use of rovalties. especially overriding royalties?

\section{DEFINITIONS}

\section{A. ROYALTY}

All royalties are rights to a portion of the production (or value of production) of one or more wells without the normal costs of drilling and producing. Royalties are usufructs and do not include any possessory rights. To induce the lessee to risk money on drilling, the lessor typically gives up the right to more than half of the value of his minerals. For example, a mineral owner who signs a lease reserving a one-fourth royalty, transfers three-fourths of the economic interest in his minerals to his lessee. Virtually all of the royalties used in the oil and gas business can be included in one of three groups discussed below. ${ }^{3}$

- Visitins Holder of the Chair of Natural Resources Law. Facuity of Law. The University of Calgary Profesear of Lew. University of New Mexico.

The aurbor pratufully seknowledges the help of Hans Hirschmunner, Al Hudee and Kevin MacFartane. who did their ben to help an American lawyer understand Canzdian oil and gas law. Any ertors that remain are due solely to the perversity of their uxudent.

The oppontuaity to scudy Canadien mineral law was aided by a grant from The Rocky Mountain Mineral Law Foundation.

I. A. R. Thompon. "A Pernpeetive on Petroleum Law" (1966) I Canadian Legal Siudies 152. Found in M. Sychuk. Cases and Marriats an Oil and Gas Low (2d ed. 1972) 4.

2. Berkhriser v. Berkteeser, [1957] S.C.R. 387. 7 D.L.R. (2d) 721.

3. See 1 D. Lewis and A. Thompson. Caradian Oil and $G_{a s}(1971)$ 106:8 H. Williams and C. Meyers. Oil and Gas Low (1982) 518, 656. 


\section{Perpetual Nonparticipating Royalties}

These are created by a mineral owner, usually before leasing, and normally give their owner a small share of any future production. Since they are perpetual, they are not dependent upon the continuation of a lease. They are called "nonparticipating" to make it clear that their owners do not share in the benefits of leases that are subsequently created.

\section{Landowner's Royalties}

These are created as a part of an oil and gas lease. They are reserved in favour of the lessor, and are normally his most important retained economic interest in the minerals during the life of the lease. When the lease terminates. the land owner's royalty created therein terminates as well.

\section{Overriding Royalties}

The important characteristic of overriding royalties is that they are granted or reserved by lessees who, in Canada, own profits à prendre which are incorporeal hereditaments.

\section{B. WORKING INTEREST}

In the vernacular of the industry, the combination of the lessee's threefourths (for example) economic interest and a property right sufficient to allow the lessee the enter upon, explore for, drill, produce and sell minerais is called a "working interest".

\section{SOME WAYS OVERRIDING ROYALTIES ARE USED}

The following is a partial list of the ways in which overriding royalties are used; it is drawn largely from the writer's experience with freehold leasing in the United States. The list is intended to give the reader some background against which to assess what would be lost if it should turn out that overriding royalties could not be created as property rights in Canada.

\section{A. RAISING MONEY AND SPREADING RISKS}

Selling overriding royalties is one of the means by which a lessee can finance the costs of drilling and spread the risks of exploration. For example, a lessee whose lessor has a one-fourth land owner's royalty has acquired three-fourths of the economic value of the leased minerals. He may be willing to sell another one-fourth interest as a way of sharing his risk. He can do this by selling an overriding royalty for one-fourth of eight-eighths. He may describe the quantum of the interest he is selling as one-third of three-fourths, since that is likely to be the way he thinks of it. The transaction is attractive to both parties. For the buyer, it is a chance to diversify by investing in areas where he does not own enough interest to consider drilling. For the seller, it is a way to hedge his bet, by realizing immediately on part of his investment, against the chance that he will drill a dry hole, and by keeping part in case he drills an oil well.

This kind of bet hedging is beneficial to the entire economy. It works toward stabilization of a volatile sector of the economy by spreading risks, and it raises money for exploration. 


\section{B. GENERATING EMPLOYEE INCENTIVE}

Granting overrides is an especially good way to compensate geologists whose efforts will determine, more than any other single factor, the success of the project. It is like a stock incentive program. It helps front-end cash flow problems, and generates strong work incentives.

\section{PROPERTY OR CONTRACT - WHAT DIFFERENCE DOES IT MAKE?}

The choice makes all the difference. In fact, it may not be going too far to say that no one in the oil and gas business, who thought about what he was doing, would intentionally create a royalty that was merely a contract.

\section{A. ROYALTIES IN CONTEXT}

It is common knowledge that oil and gas ventures require huge amounts of capital and that only a small fraction of them are successful. The investor is betting that many losses will be more than made up by a few, big successes. Two specific characteristics generated by these conditions are important in understanding the role of royalties:

1. The incentive sufficient to induce these high risk investments is the hope of receiving a share of production from successful ventures.

2. Good investment decisions in the oil and gas business should be based upon good geological information, and geological information is information about land.

Property-royalties fit these needs in a specific way. They are an investment in the success of a particular piece of property, not in a particular operator or company. Other legal devices exist for investing in the success of a particular person or company. Investment in properties is the most common motivation for furnishing drilling capital, and property-right royalties are the legal interest by which this is normally accomplished. Can it be accomplished by contractroyalties?

What is a contract-royalty? There are two possibilities:

1. A right in oil and gas produced from the described land by a contracting party; or

2. A right in oil and gas, produced from the described land, which can be claimed only from a contracting party, regardless of who owns the oil and gas.

Possibility number one, with its double limitation, is unlikely either as a judicial interpretation or as an interest on which anyone would spend money.

Number two is also a very strange interest. It could turn into number one if the contracting party became judgment proof. Barring that, number two creates an obligation to pay a fraction of someone else's production. It is quite possible, if not likely, that the contracting party, having sold the working interest, will not own any of the production which is the measure of its financial obligation.

It is suggested that no one who thought about what he was doing would intentionally give or accept real consideration for a contract-royalty. Contractroyalties would be intentionally created only as icing, attached for bargaining purposes, to arrangements for which the real consideration lay elsewhere. 


\section{B. OVERRIDING ROYALTIES IN CONTEXT}

Everything that has been said above about royalties in general is equally true of overriding royalties. Overrides are a pure investor's interest in the oil and gas potential of a specific tract of land. They differ from other royalties only in that they are granted or reserved only from the working interest rather than the whole of the mineral interest. The loss of overrides as a viable investor's interest would be a severe blow to any oil and gas producing jurisdiction.

\section{WHAT IS NEEDED}

Royalties need to be investments in the mineral potential of a specific tract of land, the burden of which runs with the mineral interest out of which they have been carved. They also need to be interests whose owners and purchasers can be protected against double conveyancing, innocent or otherwise. Covenants real have been considered and rejected for this purpose. Unfortunately, royalties do not closely enough meet the traditional requirements for covenants real. ${ }^{4}$ The only practical way to achieve these goals is to create royalties as real property interests in the mineral estate.

\section{THE CONCEPTUAL PROBLEMS}

\section{A. MINERAL AND LEASE OWNERSHIP THEORIES}

The fee simple owner (whether private or Crown) of a mineral estate in Canada owns a corporeal interest in the oil and gas in situ. ${ }^{5}$ When this absolute owner conveys an oil and gas lease, however, the lessee receives only a profit $\grave{a}$ prendre in the oil and gas. 6

\section{B. ROYALTY OWNERSHIP THEORY}

At English common law, there was no property interest called a royalty. If, in the absence of legislation, oil and gas royalties are to be recognized as interests in property, they must be analogized to a pre-existing common law category. Only three categories have been suggested for this purpose: ${ }^{7}$

1. An undivided fractional interest in the lessor's retained fee interest;

2. An undivided fraction of a profit à prendre;

3. A rent or an interest analogous to rent.

Suggestion one, a fractional interest in the minerals, may be feasible in Canada for the categorization of perpetual nonparticipating royalties and

4. $2 \mathrm{H}$. Williams and C. Meyers, Oil and Gas Law, (1981) §324.4. For a general statement of the requirements for creating convenants that run with the land, see E. H. Burn, Cheshire and Burn's Modern Law of Real Property (13th ed. 1982) 429 et seg.

5. In Borys v. C.P.R. and Imperial Oil (1953) 7 W. W. R. (N.S.) 546 at 559, the Privy Council announced its now famous obiter:

For the purpose of this decision their Lordships are prepared to assume that the gas whilst in situ is the property of the appellant even though it has not been reduced into possession

Since the Borys case, no Canadian case has suggested an ownership theory other than absolute ownership.

6. Supra n. 2.

7. G. J. Davies, "The Legal Characterization of Overriding Royalty Interests in Oil and Gas" (1972) 10 Alta. L. Rev. 232 at 237. 
landowner's royalties where these are granted or reserved by the owner of the mineral fee. It would, however, be unsuitable for the categorization of an overriding royalty, because an override is granted or reserved by a lessee. who, in Canada, owns only a profit $\dot{a}$ prendre.

Suggestion two, an undivided fraction of a profit a prendre. could be seen as an undivided interest in a profit à prendre stripped of its execurive powers. The trouble with this is that royalties are entitled to their fractional share of production free of the ordinary costs thereof. The lessee's profit $\dot{a}$ prendre. on the other hand, is not a cosi-free interest, since its owner must contribute to the costs of development. Also, a profit ì prendre is a possessory estate and a royalty is not. Unilike a profit a prendre, a royalty is an investor's interest in minerals.

Suggestion three, rent or an interest analogous to rent, is the most defensible suggestion conceptually. This theory has been at least tacitly accepted by almost all Canadian and American jurisdictions, and has been express!y approved by the Laskin $J$. as he then was. ${ }^{9}$ For centuries. English common law has recognized rent as a real property interest in land. The availability of the concept of rent for categorizing overriding royalties in Canada. however, has been questioned because of what is herein referred to as the "no rent on a rent" rule. Megarry and Wade have succinctly stated the rule:9

\begin{abstract}
At comruan law a reatcharge could be charged only upon a corporeal heseditament. There could be no renteharye charged upon anocher rentcharge or orher incorporeal hereditament. since obviously these could then be no right of distress. But this teetnical obstacle was removed both for the past and ior the furure by the Law of Property Act. 1925....
\end{abstract}

This "technical obstacle" may not affect perpetual or land owner's royalties ${ }^{10}$ since they are assigned or reserved out of a fee interest in the minerals." It would apply only to royalties created by one who owns an incorporeal interest in the minerals, but this is exactly what overriding royalties are, since they are, by definition, assigned or reserved by lessees who, of course, own profits à prendre.

\title{
C. CANADIAN CASES
}

The several Canadian cases which have held that the royalty in question was a mere contractual right appear to have done so as a matter of construction of the particular lease. No Canadian cour has held that overriding royalties cannot be created as a property interest on the grounds that a rent cannot be created out of a rent. In fact, some of the cases that might appear to support the argument that property-right overrides cannot be created do not involve overriding royalties at all.

In Vanguard Petroleum Lid. v. Vermont, 12 the lessor, who owned a corporeal interest in the minerals in siru, conveyed the royalty in question to his lessee, Vanguard Petroleum Lid., in return for Vanguard's surrender of the lease.

8. See infre n. 16 and accompanyiag text.

9. Meparty and Wade, The Low of Real Propersy (4ih ed. 1975) 794

10. These incerests are derined in the text supro at Part II. A.

11. Bur see the text, infro. al Pan VIf. B. I. where It is sugaested that an argument could be made thac the "no reat on a reat" rule could aftect all royalties.

12. [1977] 2 W. W.R. 66 (Alk. S.C.). 
Presumably, this was a perpetual nonparticipating royalty. The Trial Judge held that the royalty was merely a contractual interest. Whatever the grounds of decision, ${ }^{13}$ the judgment could not have been based upon the "no rent out of a rent" rule, 14 because the creator of the rovalty owned a corporeal interest in the minerals.

The same point can be made about Fuller v. Howell. 15 In the Fuller case, the owner of a farm granted an oil and gas lease for a primary term of three.years, reserving to himself a one-seventh royalty. While this lease was still in effect, the farmer sold his farm to $X$. and his royalty to $Y$. When $Y$ tried to collect one-seventh of production under the royalty, the Ontario High Court held that the rovalty was a mere contract and that $Y$ could only collect it from the farmer who had sold it to him. Again, whatever the grounds of decision, the judgment could not have been based upon the "no rent on a rent" rule, because the royalty was a land owner's royalty which had been reserved by the farmer when he executed the oil and gas lease.

\section{Saskarchewan Minerals v. Keyes}

The leading Canadian case involving an overriding royalty is Saskatchewan Minerals v. Keyes. ${ }^{16}$ Although the Keyes case dealt with alkali, it is equally applicable to fugacious minerals. Mr. Keyes had obtained an option to purchase two Crown leases from one Harvie, the lessee. He then sold his options to Astral Mining \& Resources Ltd. in return for a rovalty of twentyfive cents per ton. Astral exercised Keyes' options and purchased the leases from Harvie. Astral then sold the leases to Saskatchewan Minerals. Keyes brought an action against Saskatchewan Minerals to recover his royalty on alkali it was producing from the leases. Keves won in the Trial Court, and the Saskatchewan Court of Appeal affirmed in part, making this important statement:"

\footnotetext{
The leamed Tnal Judge held that under and by vinue of the option. Keyes oblained an iaterast is the land. I agree

In result. I am of the opinion that. if one having an interest in the "land" grants an assignment or lease of that interest. reserving a roỵalty, payment of that royalty binds a subsequent assignee.
}

Since the Supreme Court of Canada reversed, on other grounds, it can be argued that the above quotation is still the law in Saskatchewan. In the end,

13. Id. at 74. The coun's opinion is based solely on its finding of the intent of the parties expresed in clause I of the rovalty agreement. Clause 3 pupported to give the prantes a right to "file and maintain a caveat against the sid lands is respect of the said gross royalty hereby granted". but. Of course that was a question of law and could not be extublished by contraet between the paries.

The problem with elause 3 was that it also required the owners to mike provision for the paymeac of the royalty if they surrendered of conveyed the "petroleum subarances". a provision that would have been unnecessary if the plaintiff s interest had been a perpetual nonpanicipating royalty. This kind of elause is frequently used in documents creating land owater's or overriding royalties (which terminate when the lease teiminstes), in order to guasd against a "washout" by fraudulent collaboration between lessee and leseor. Since the issue was whether the royalty was aveatable. clause 3 did not help the plaintiff.

14. This rule would be more accurately labelied "the no rent on a rent or other incorporeal interesi" rule. See supeo n. 9

15. (1942) | D.L.R. 46210 nt. H. Ct.)

16. [1972] S.C.R. 703. [1972] 2 W.W.R. 108.

17. (1970) 12 D.L.R. (3d) 637 at 64 S. 
Saskatchewan Minerals did not have to pay the rovalty to Keves because the Supreme Court held that the royalty was a mere contractual right. enforceable only against Astral. The majority opinion was based upon the Saskatchewan Alkali Mining Regulations which required that conveyances of interests in the minerals be approved by the Minister. Hence. if the toyalty was a property interest in the minerals, it could not be conveyed without consent. The conveyance of the option from Keyes to Astral failed and with it the royalty Keyes reserved as consideration.

In an interesting dissenting opinion, Laskin J., as he then was, with Hall J. concurring, suggested that the rent analogy was an apt one for rovalties and that the ancient rule that a rent could not be created out of an incorporeal interest would not be an impediment to the application of the rent analogy to overriding royalties in Canada. After stating the "no rent on a rent" rule of pre-1925 English law, Laskin J., as he then was, said: ${ }^{18}$

\footnotetext{
That the unaccrued royalty in such case is regarded as an interest in land. and remains so although transferred separately trom the fee simple in the surface and the "reversionary" "interest in the minerals or in the oil and gas. appears to be the prevaling view in the Linited States: see 3A Summers. Oil and Gas, 1958. I agree with this characterization because 1 do not think that there should be any distunction between the foregoing sttuation and that which would exist if the devisee had an interest in reversion in the strict sense.
}

Laskin J., as he then was, concluded his discussion of this issue with the following comment:19

\footnotetext{
He beame entitled to an overriding royalty. ... whether that interest was a leasehold in the stnct sense or a profit a prendre for a term: and the rovalty. unaccrued. was an interest in land. analogous to a rent-charge. and. in the circumseances. binding on the appellant as subsequent assignee of (the lease).
}

Thus, in the only Canadian case in which the issue was raised, two Justices expressed the opinion that overriding royalties in Canada can be created as interests in land, and the majority of the Court decided the case on grounds that had nothing to do with the power to grant and reserve property-right royalties.

\section{Royaity As A "Mere" Contract}

In addition to being undesirable from the viewpoint of the owner, contract royalties constitute an unnecessary risk for the operator. If overriding royalties are not property interests, then they must be contractual obligations. As such they become impediments to the traditional methods of doing business in the oil and gas industry. The prospect of creating a contractual, albeit contingent, liability at a time when the lessee-grantor does not know whether he will be the operator or even have an interest in production, should discourage the use of such "royalties" by anyone who thinks about what he is doing. ${ }^{20}$

18. [1972] 2 W. W.R. 108 al 122.

19. Id at 125 .

20. If the pany obligated to pay a contract-royalty is not able to obiain a novation when it assigns the mineral interest. it may remain liable to pay a fraction of someone etse's production. production about which it may have no knowiedge or even the ability to obtain knowledge. 


\section{ROYALTY LAW IN THE UNITED STATES}

The differences between corporeal and incorporeal interests in oil and gas developed differently in the United States than they have in Canada. The first and most important difference is the nature of the mineral owner's estate. Scholars agree that there are only two ownership theories in America today.21 One is called the "ownership in place" theory, and th: other is called either the "qualified ownership" theory or the "non-ownership" theory. The significant point is that, in "ownership in place" states, the mineral owner owns his minerals just as mineral owners do in Canada, that is, he owns a corporeal estate, in siru. In the other states, a corporeal estate in fugacious minerals in situ is impossible, and mineral owners have only a profit à prendre until the minerals are reduced to possession. In non-ownership or qualified ownership states the highest estate anyone can have in oil and gas in place is the same estate that lessees have in Canada. In these non-ownership states the lessor can, of course, assign no greater interest than he owns - a profit à prendre.

Williams and Meyers have this to say about the analogy between royalty and rent in the American states:22

\footnotetext{
It is aot sugested that royalty and miperal interests can be made to fit the concept of reat exncty. At least three objections to the assimilation can be pointed out: (1) Common-law rent was periodic and recurring. while ... rovalty may never accrue. (I) Common-iaw rent was denved from the profit an the had and not from the land itself. Royaliy, on the other hand. derives from the corpus of the land. (3) Commondaw rent could not issue from an ineorponal heredilament, while ... royalty may istue from a profir os prendre, the interest created by an oil and gas lease in many states. Despice these objections to the analogy. cours have genenlly assimilated ... royalty to the incorporeal hereditament of reat. at leat for some purposes. (F counotes omitted)
}

Nevertheless non-ownership and qualified ownership states, such as California, have not questioned the status of royalties as incorporeal property interests in minerals. One practical reason for this may be that where all interests in minerals are profits a prendre, a rule that royalties could not be created out of incorporeal estates would destroy all royalties. It would, thus, destroy the oil and gas business as it is conducted today. In Canada, it would apparently destroy overrides only, but overrides are very useful interests, and the industry should not be unnecessarily denied them. Also, many thousands have been created in Canadian minerals. Almost all of these were surely intended to be interests in the minerals in and under a particular piece of land.23

By definition, an analogy is not a copy. The question is: in analogizing royalty to rent, is the "no rent out of an incorporeal estate" rule necessary to the analogy? If it is, then overriding royalties are worse than useless in Canada unless their status is changed by legislation. ${ }^{24}$

21. See I H. Williams and C. Meyers. Oil and Gas Law (1981) 201.

$222 \mathrm{H}$. Williams and C. Mevers. Oil and Gas Law (1981) $\$ 324.4$.

23. The argument here is that made in the text. mpro a Pan IV. A.

24. Worse from the grantor's viewpoint because it remains liable even after ut no longer owns an interest in the minerals. and worse from the granter's newpoint because its interest is limited to both the specific land described and collectable from a specific legal pesson - ts grantor. 


\section{ROYALTY AND RENT - THE PROPER SCOPE OF THE ANALOGY}

\section{A. DEFINITIONS OF CONCEPTS NECESSARY TO THE ARGLMENT}

\section{Distress}

Distress is a summary remedy by which the lord is empowered to enter and lake possession of the tenant's personal property until the services are rendered. Under the English system of tenures, at least since the Norman conquest, the lord's right of distress for failure to receive services was a part of the elaborate system of tenures and services which held sociery together. Today, the right of distress exists, where it exists at all, 25 as a remedy for the collection of rent. 26

\section{Rent}

Early common law distinguished three kinds of rent:27

1. "Rentservice": the return due from a tenant to the reversioner;

2. "Rentcharge": a return made payable out of land to one without a reversionary interest where a right of distress is expressly reserved;

3. "Rentseck": rent made payable out of land to one without a reversionary interest where a right of distress was not reserved.

When the Landlord and Tenant Act, $1730^{28}$ granted a right of distress to rentseck, it became indistinguishable from rentcharge. In a rentservice, the lord kept a reversionary interest in the land, which automatically gave him a power to distrain for rent due. In a rentcharge, the lord did not keep a reversionary interest, and he had a power to distrain only if he expressly reserved it in the document reserving the rent. And, a power to distrain could only be reserved out of a freehold (corporeal) estate.

\section{B. ARGUMENT}

At English common law prior to the reforms of 1925,29 a rent could not be created out of a rent or other incorporeal interest. The reason given for this rule was that to be a rent the interest had to be enforceable by the right of distress, and the right of distress belonged only to an owner whose interest was corporeal. 30

The remedy of distress, however, was not always a prerequisite for rent. Before 1730 , a rent could be created with no power of distress. It was called a rentseck. ${ }^{31}$ In the Landlord and Tenant Act, 1730,32 Parliament provided that

25. The remedy of distress has been abolished in at least one Australian state. see $R$. Brooking and $A$. Chernov. Tenancy Low and Procuce. Victoria (1972) 309. and most American states. see Tiffany, The Low of Real Propeny (3d ed. 1939) \$879.

26. Bum, supra n. 4 ai $\$ 12$.

27. Id a 410 ef seq. for a good discussion of tent.

28. Landlord and Tenant Act. 1730 (U.K.), 2 Geo. 2, c. 28. s. 5.

29. For an account of the reforms of 1925 see supran. 9 at 9 . The parricular legislation referred to in the texi is the Law of Property Aet. 1925 (U.K.). is \& 16 Geo. S. c. 20.

30. Sie supre n. 9 and accompanying text.

31. Supre n. 9 at 799.

32. Supren. 29. 
rentseck could be collected by distress even though there was no tenural relation between the parties and no such remedy had been contractually agreed to. It was sometime after 1730 that the remedy of distress changed from a remedy to a presequisite for rent. Before 1730 , rents were created in the absence of a right of distress, and called rentseck.

\section{Royalty And The Remedy Of Distress}

Even as to oil and gas rovalties granted or reserved by the owner of a fee simple absolute in the minerals, one can find no case that has allowed the royalty owner to use the remedy of distress. Nor would one expect to find one. The idea that royalty owners could summarily seize drilling and producing equipment worth millions of dollars, especially in fields where drainage might be going on, is unthinkable. It would be putting a pistol in the hands of royalty, or alleged royalty, owners.

Royalty which is an interest in minerals in situ, needs no summary right to seize personal property. Its status as a property interest in the minerals in place gives owners entirely adequate remedies while protecting bona fide purchasers. It is unthinkable that any Court would ever extend the remedy of distress to a royalty owner. Why bring the corporeal estate requirement, which is based upon distress, along with the analogy? It would make as much sense to say that all royalties are mere contracts because distress does not lie for their collection. The analogy between rent and royalty does not include distress. Therefore, whether distress would lie in a particular instance is not a test for whether a royalty may be reserved. Distress would not lie for the enforcement of any kind of royalty.

\section{CONCLUSION}

Royalties, as used in the oil and gas industry, make sense only if they are property interests in unproduced minerals. Owners of mineral rights should be able to create them as such if they make clear their intent to do so. There is nothing in Canadian law to make this impossible. It has been specifically allowed by the Saskatchewan Court of Appeal, and Laskin J., as he then was, of the Supreme Court of Canada has expressed his agreement in clear and unmistakable language. 